Department of Economics- FEA/USP

\title{
Do temperature shocks affect non-agriculture wages in Brazil? \\ Evidence from individual-level panel data
}

\author{
JAQUELINE OLIVEIRA \\ BRUNo Palialol \\ Paula PEREDa
}

Working PAPER SERIES № 2021-13 


\title{
Do temperature shocks affect non-agriculture wages in Brazil? Evidence from individual-level panel data
}

\author{
Jaqueline Oliveira (oliveiraj@rhodes.edu) \\ Bruno Palialol (bruno.palialol@usp.br) \\ Paula Pereda (pereda@usp.br)
}

Research Group: NEREUS and EconomistAs [Brazilian Women in Economics]

\begin{abstract}
:
The relationship between temperature and agriculture outcomes in Brazil has been widely explored, overlooking that most of the country's labor force is employed in nonagriculture sectors. We use monthly individual-level panel data spanning January 2015 to December 2016 to ask whether temperature shocks impact non-agriculture wages in formal labor markets. Our results show that a $1^{\circ} \mathrm{C}$ shock increases wages where climate are colder, but reduces wages where climate are hotter. We calculate that wages fall $0.42 \%$ on average, an income loss equivalent to $0.06 \%$ of GDP annually. Assuming future temperatures rise uniformly by $2^{\circ} \mathrm{C}$, and that no adaptation occurs, we expect annual income losses five times larger. The heterogeneous effects we find also suggest that weather vulnerability may deepen existing income inequalities.
\end{abstract}

Keywords: temperature shocks; labor productivity; nominal wage exibility; non-agriculture sector; formal labor markets.

JEL Codes: C23; J24; Q54 


\title{
Do temperature shocks affect non-agriculture wages in Brazil? Evidence from individual-level panel data*
}

\author{
Jaqueline Oliveira $^{\dagger} \quad$ Bruno Palialol $^{\ddagger} \quad$ Paula Pereda $^{\S}$
}

August 3, 2020

\begin{abstract}
The relationship between temperature and agriculture outcomes in Brazil has been widely explored, overlooking that most of the country's labor force is employed in nonagriculture sectors. We use monthly individual-level panel data spanning January 2015 to December 2016 to ask whether temperature shocks impact non-agriculture wages in formal labor markets. Our results show that a $1^{\circ} \mathrm{C}$ shock increases wages where climate are colder, but reduces wages where climate are hotter. We calculate that wages fall $0.42 \%$ on average, an income loss equivalent to $0.06 \%$ of GDP annually. Assuming future temperatures rise uniformly by $2^{\circ} \mathrm{C}$, and that no adaptation occurs, we expect annual income losses five times larger. The heterogeneous effects we find also suggest that weather vulnerability may deepen existing income inequalities.
\end{abstract}

JEL Codes: C23, J24, Q54

Keywords: temperature shocks, wages, labor productivity, nominal wage flexibility, non-agriculture sector, formal labor markets.

\footnotetext{
${ }^{*}$ We are indebted to two anonymous referees for their invaluable comments and suggestions. Special thanks to The Regional and Urban Economics Lab (NEREUS) at the University of São Paulo for providing access to the data and their Server. Any errors are our own.

${ }^{\dagger}$ Rhodes College. E-mail: oliveiraj@rhodes.edu.

${ }^{\ddagger}$ University of São Paulo. E-mail: bruno.palialol@usp.br.

$\S$ University of São Paulo. E-mail: pereda@usp.br.
} 


\section{Introduction}

The link between temperature and economic outcomes in agricultural markets around the world and, in particular, in Brazil, has been the subject of much research. ${ }^{1}$ But despite Brazil's agriculture sector being of great relevance for the country's economy, the majority of its population lives in urban areas, and most of the country's labor force is employed in non-agriculture sectors. ${ }^{2}$ A complete picture of the economic effects of temperature variations requires, therefore, the analysis of outcomes for those employed in non-agriculture activities. And yet, the empirical evidence on the existence and magnitude of such effects, especially using detailed individual-level data, is scant. ${ }^{3}$ This study seeks to fill in this gap.

In this paper, we analyze the effects of short-term temperature shocks on Brazil's nonagricultural labor markets. In particular, we focus on individual wages. To that end, we leverage rich data from administrative records covering the universe of Brazilian formal workers and their workplaces. After we draw a random sample from the universe, we end up with a panel of 222,174 workers for whom we observe monthly data on wages, hours worked, firm, sector and municipality of employment, and other labor market outcomes, covering

\footnotetext{
${ }^{1}$ Mendelsohn et al. (1994) and Schlenker et al. (2005) use cross-sectional data on land values to estimate climate effects on agriculture production. More recently, the literature uses panel data to identify temperature effects on agricultural profits/yields. See Deschenes and Greenstone (2007) and Schlenker and Roberts (2009) for U.S. and Schlenker and Lobell (2010), Feng et al. (2010) and Welch et al. (2010) for developing countries. For studies which focus on the Brazilian context, see Assad et al. (2004), Sun et al. (2007), Barbarisi et al. (2007), Assad et al. (2013) and Silva et al. (2019) for weather effects on specific crops, and Massetti et al. (2013), Araújo et al. (2014), Pereda and Alves (2018), Castro et al. (2019), and Oliveira and Pereda (2020) for weather and climate effects on agricultural outcomes.

${ }^{2}$ Data from Brazilian Household Survey (2019) and Population Census (2010) reveal that $84.4 \%$ of Brazil's population lives in urban areas and $90 \%$ of the labor force is employed in non-agriculture sectors.

${ }^{3}$ Dell et al. (2014) review the empirical evidence on non-agricultural outcomes, such as labor productivity, migration and human health. The focus of these studies is mostly on human health. Most studies assess the effects of cold and heat on mortality rates, mainly for infants and the elderly (Deschenes and Greenstone, 2011; Barreca et al., 2015, 2016; Burgess et al., 2017). See Deschenes (2014) for a review of the impacts of extreme temperatures on human health.
} 
January of 2015 through December of $2016 .{ }^{4}$ We then merge daily weather data to the panel using information on workers' municipality of employment.

We argue that our panel data analysis based on monthly wage and weather data presents important advantages. As we show in Figure 1, there is considerable wage variation in our sample, both in nominal and real figures. ${ }^{5}$ Thus, we would be missing much of the movement in wages that occurs within a year if we employed annual data instead. Furthermore, because we are interested in the short-term effect of temperature shocks, monthly data represent a more unexpected change to assess the consequences of extreme temperatures. ${ }^{6}$ Finally, climate change is expected to increase unevenly across seasons in Brazil as winter temperatures might increase $1^{\circ} \mathrm{C}$ more than summer temperatures between 2070-2099. ${ }^{7}$ The data, therefore, allow us to explore differential effects by month and understand future changes in weather at a finer level of disaggregation.

We present estimates of the impact of monthly temperature deviations from the monthly climate temperatures (i.e. historical averages) on individual-level hourly wages after including municipality-year, month, worker, and firm fixed effects. Our specification accounts for potential non-linearities by allowing for the effects to depend on the levels of municipalities' monthly climate temperatures. We find that in places and months where climate tempera-

\footnotetext{
${ }^{4}$ We choose 2015 and 2016 because these are the years when monthly wage data are available and can be matched to monthly weather data at the municipality level.

${ }^{5}$ Nearly $70 \%$ of the month-to-month percent change in wages is different from zero and, among non-zero changes, close to $80 \%$ lies in the $-20.8 \%$ and $+29.9 \%$ range.

${ }^{6}$ Many papers of the literature on weather effects on infant health normally use monthly or bi-monthly panel data (Barreca, 2012; Wilde et al., 2017; Banerjee and Maharaj, 2020). Jacob et al. (2007) and Ranson (2014) explore monthly and weekly panels to investigate the weather (temperature and/or precipitation) effect on criminality rates in the United States.

${ }^{7}$ While summer temperatures might increase from $2.3^{\circ} \mathrm{C}$ to $3.9^{\circ} \mathrm{C}$ between $2070-2099$ depending on the Brazilian region, winter temperatures can rise from $3.3^{\circ} \mathrm{C}$ to $4.9^{\circ} \mathrm{C}$ during the same period in the most pessimistic scenario. The calculations are based on CPTEC/INPE (Center for Weather Forecasting and Climate Studies of the National Institute for Space Research) forecasts for the A2 scenario by comparing 2070-2099 average with 1980-2010 average.
} 
tures are below $18^{\circ} \mathrm{C}$, a $1^{\circ} \mathrm{C}$ temperature shock increases wages; for temperatures above the $18^{\circ} \mathrm{C}$ threshold, on the other hand, we estimate significant negative effects on wages from the same increase. Taking the extreme case of climate temperatures around $30^{\circ} \mathrm{C}$, for example, our estimate points to a $0.96 \%$ reduction in wages resulting from $1^{\circ} \mathrm{C}$ shocks. When we calculate the marginal effect of sustained $1^{\circ} \mathrm{C}$ shocks each month across the climate temperature distribution over the year 2015, our results show that hourly wages fall $0.42 \%$ on average. This figure corresponds to annual income losses for workers in the formal sector of US\$ 1.1 billion, which is equivalent to $0.06 \%$ of Brazil's GDP in 2015.

Uncomfortably high or low temperatures may lead to harmful workplace environments, especially for workers performing their jobs outdoors or in non-climate-controlled facilities (Ramsey, 1995; Pilcher et al., 2002; Seppänen et al., 2006). If labor supply is inelastic in the short-run, worker productivity losses could result in lower short-term wages in labor markets featuring predominantly temporary employment. Because our study focuses on formal labor markets characterized by long-term employment contracts, however, a more plausible explanation for our results could be that workers and firms engage in (implicit) risksharing labor contracts where workers accept lower nominal wages to avoid layoffs (Franklin and Labonne, 2019). Therefore, we look at other employment outcomes to shed light on whether employment contracts are affected by transitory temperature shocks and we find no effect on workers switching to temporary contracts or other payment schemes. ${ }^{8}$ We, therefore, conclude that any adjustment to employment contracts is likely done through wages, since we do find significant effects on nominal wages.

Another concern we face is that weather shocks could have affected individual's labor

\footnotetext{
${ }^{8}$ The majority of workers were permanent (98\%) and under a monthly payment scheme (93\%).
} 
market mobility. If workers respond to temperature shocks by migrating out of their current municipality, changing sectors, or switching employers, any temperature-wage relationship estimated from municipality-level data could be reflecting changes in job types and labor force composition. Because our analysis exploits a rich panel data on individuals and firms, we can empirically check for this mechanism. Our estimates indicate that there is a significant impact on the likelihood an individual changes sector or firm, but not municipality. We do not believe, however, that these changes explain the wage effects we find for two reasons. First, the percent of workers that changed sector or firms within the period we study is very small (4\% and 9\%, respectively). Second, our estimates remain unchanged when we estimate the effects on a sample of workers that never moved. Finally, and more importantly, the estimates with and without worker and firm fixed effects differ very little. We take this as suggestive evidence that these transitions have a limited role in explaining our results.

Because our premise is that harmful labor productivity effects from extreme temperatures is what drive the link between temperature and wages, it is reasonable to ask whether workers are affected differently depending on the degree to which they are exposed to the weather when performing their jobs. While we do not have direct data on workplace characteristics, we rely on detailed information on workers' occupation to classify them into "exposed" and "less exposed" groups. The estimates are only significant among "exposed" workers.

This paper contributes to the strand of the literature that studies wage adjustments to transitory economic and environmental shocks (Jayachandran, 2006; Kaur, 2019; Franklin and Labonne, 2019). ${ }^{9}$ More closely related to our setting, and also exploiting individual-

\footnotetext{
${ }^{9}$ See also Zivin and Neidell (2014), Deryugina and Hsiang (2014), Dell et al. (2014), Barreca et al. (2016) and Behrer and Park (2017) for how climate change and weather impacts other labor market outcomes.
} 
level data, Franklin and Labonne (2019) find that, in Filipino non-agriculture labor markets, nominal wages adjust downwards in response to a large environmental shock, typhoons. In line with their findings, our paper offers support for nominal wage flexibility in the context of labor markets characterized by long-term employment contracts. What sets us apart, however, is that we show evidence of wage adjustments in response to a smaller and more commonplace shock, short-term temperature increases. Furthermore, our ability to capture heterogeneous impacts along the distribution of climate temperatures helps to shed light on how climate change may affect the magnitude of wage adjustments to short-term temperature shocks.

This paper also dialogues with the literature that investigates the link between temperature and labor productivity in non-agriculture sectors for developing countries (Zhang et al., 2018; Somanathan et al., 2018; Cai et al., 2018; Chen and Yang, 2019; Adhvaryu et al., 2020; Colmer, 2020). The empirical studies in this literature employ actual measures of worker output and can provide more direct evidence of the negative impacts of extreme temperatures on worker performance. We contribute to this literature by providing evidence that the adverse effects on performance may translate into lower individual incomes, even when temperature increases are temporary. Our analysis also covers a wider range of economic sectors and regional climates, as we focus on the universe of Brazilian formal workers.

This paper is organized as follows. Section 2 outlines our empirical strategy and discusses identification of temperature effects from individual-level panel data. Section 3 describes the monthly wage and weather data. Section 4 presents our main results on the temperaturewage relationship. Sections 5, 6 and 7 discuss additional results, robustness checks, and heterogeneous effects. Section 8 offers some big-picture insights drawn from our results. 


\section{Empirical approach}

To understand the impacts of weather and climate on economic outcomes, the standard panel approach typically distinguishes weather from climate impacts. A weather variable is a realization from a climate distribution. As Dell et al. (2012) highlight, weather variables have strong identification properties. On the other hand, climate effects are difficult to identify since climate variables are time-invariant and, therefore, dropped from the estimates when we include individual or regional fixed effects.

We choose to identify temperature effects by employing a temperature deviation variable — the monthly temperature deviation from the historical average - and its interaction with the historical average (or climate). The temperature deviation measures short-term temperature shocks. And because our estimation rests on monthly temperature variation as an identifying source, we ultimately rely on the short-term weather unpredictability for causal inference.

The temperature shock interaction with the climate variable allows for the effects to depend on the baseline climate. This means, for example, that one-degree changes in temperature deviations from climate averages may have a different impact on colder places (or colder seasons) than on warmer places (or warmer seasons). The goal is to distinguish the temperature effects in hotter places, when climate temperatures are already high, from the effects in colder places. To that end, we propose the following model:

$$
\log \text { wage }_{i f c m t}=\alpha_{0}+\alpha_{1} \Delta T e m p_{c m t}+\alpha_{2} \Delta T e m p_{c m t} * \bar{T}_{c m}+\beta Z_{c m t}+\alpha_{i}+\alpha_{f}+\alpha_{m}+\alpha_{c t}+\epsilon_{i f c m t},
$$


where wage $_{\text {ifcmt }}$ is the real hourly wage of worker $i$ employed by firm $f$ located in municipality $c$ in month $m$ of year $t ; \Delta T e m p_{c m t}=\left(T e m p_{c m t}-\bar{T}_{c m}\right)$ denotes the temperature deviation from the climate temperature in municipality $c$ in month $m$ of year $t$, and $\bar{T}_{c m}$ is the municipality's climate temperature in month $m .{ }^{10}$ We also include controls for precipitation $\left(Z_{c m t}\right)$ and use the same functional form as we use for temperature. The remaining parameters, $\alpha_{i}, \alpha_{f}, \alpha_{m}$, and $\alpha_{c t}$, denote worker, firm, month, and municipality-year fixed effects, respectively; $\epsilon_{\text {ifcmt }}$ is the idiosyncratic error term. These fixed effects are key for identifying the short-term causal effects of temperature on wages. First, municipality-year fixed effects hold constant time-invariant municipality attributes, such as historical and cultural determinants of regional economic development, which are correlated with long-term climate; they also absorb annual shocks to local labor markets that are potentially associated with climate conditions. Month fixed effects are key to control for weather seasonality that may coincide with economic seasonality that causes labor markets to be more active. Individual fixed effects allow us to account for changes in workforce skill composition, both observed and unobserved, spurred by weather shocks within a municipality. Firm fixed effects help us control for firm-level unobservable characteristics such as endogenous adoption of climate-control technology, as well as changes in the sector/industry mix within a municipality.

In addition to the average temperature and its monthly deviations to examine the effects of temperature on wages, we adopt an approach based on temperature bins, first employed by Deschenes and Greenstone (2011). The idea is to consider how often temperatures fall into specific ranges. Despite being more flexible than other functional forms, this approach can

\footnotetext{
${ }^{10}$ We calculate the climate temperature as the long-term temperature for a given month in each municipality. We do this by taking the average of the month over the entire period of historical weather data, from 1980 to 2016.
} 
be arbitrary when defining the bins' ranges, and might lead to biased estimates depending on how data is aggregated (Dell et al., 2012). We choose the bins specification below:

$$
\log \text { wage }_{i f c m t}=\beta_{0}+\sum_{j=1}^{8} \beta_{j} \operatorname{Temp}_{c m t}^{j}+\sum_{h=1}^{9} \beta_{h} \operatorname{Rain}_{c m t}^{h}+\alpha_{i}+\alpha_{f}+\alpha_{m}+\alpha_{c t}+\epsilon_{i f c m t},
$$

where $T e m p_{c m t}^{j}$ is the number of days in municipality $c$, month $m$ of year $t$ that fall in temperature bin $j$. $\operatorname{Rain}_{c m t}^{j}$ is the number of days in municipality $c$, month $m$ of year $t$ that fall in precipitation bin $j$. We employ the following temperature bins: below $12^{\circ} \mathrm{C} ; 12$ to $15^{\circ} \mathrm{C} ; 15$ to $18^{\circ} \mathrm{C} ; 18$ to $21^{\circ} \mathrm{C} ; 21$ to $24^{\circ} \mathrm{C}$ (base category); 24 to $27^{\circ} \mathrm{C} ; 27$ to $30^{\circ} \mathrm{C}$; and above $30^{\circ} \mathrm{C} .{ }^{11}$ The set of fixed effects are the same as in Equation (1).

Finally, we use harmful degree days (HDD $)^{12}$ to capture the effect of extreme hot temperatures on wages according to the equation below:

$$
\log \text { wage }_{i f c m t}=\gamma_{0}+\gamma H D D_{c m t}+\beta Z_{c m t}+\alpha_{i}+\alpha_{f}+\alpha_{m}+\alpha_{c t}+\epsilon_{i f c m t},
$$

where $H D D_{c m t}$ is the sum of variable $H D D_{d c m t}$ in month $m$ of year $t . H D D_{d c m t}$ counts

\footnotetext{
${ }^{11}$ For precipitation, we employ the following bins: $0 \mathrm{~mm} ; 0$ to $0.05 \mathrm{~mm} ; 0.05$ to $0.26 \mathrm{~mm} ; 0.26$ to $0.8 \mathrm{~mm}$; 0.8 to $1.8 \mathrm{~mm} ; 1.8$ to $3.6 \mathrm{~mm}$ (base category); 3.6 to $6.7 \mathrm{~mm} ; 6.7$ to $12.8 \mathrm{~mm}$; and above $12.8 \mathrm{~mm}$. We set the first precipitation bin to $0 \mathrm{~mm}$ because around $21 \%$ of the precipitation values in our sample are zero; we separate the other eight bins (to match temperature bins) so that every bin had approximately the same number of observations.

${ }^{12}$ See Schlenker et al. (2006) for an application using harmful degree days for agriculture, and Jessoe et al. (2018) and Liddle (2018) for applications in non-agricultural markets. Harmful degree days is also referred in the literature as killing degree days (Butler and Huybers, 2013, 2015).
} 
the degree days above an specific threshold $\left(30^{\circ} \mathrm{C}\right)^{13}$ in month $m$ of year $t$ :

$$
\begin{aligned}
H D D_{d c m t} & =\left(T_{d c m t}-30\right), \text { if } T_{d c m t}>30 \\
& =0, \text { if } T_{d c m t} \leq 30,
\end{aligned}
$$

where $T_{d c m t}$ is the observed temperature on day $d$ (of month $m$ of year $t$ ) in municipality $c$.

To estimate the parameters from Equations (1), (2), and (3) we utilize administrative employer-employee panel data on labor market outcomes, where information on wages is available on a monthly basis, and municipality-level monthly weather data. The next section describes the data sources and summarizes the variables of interest.

\section{$3 \quad$ Wage and weather data}

\subsection{Employer-employee panel}

We source worker-level data on monthly wages from RAIS (Annual Social Information Report), which is an employer-employee administrative database covering $99 \%$ of the formal labor force, starting in January of 2015 and ending in December of $2016 .{ }^{14}$ We draw a random sample of $1 \%$ of the universe of workers and match them with weather information using the municipalities where the job is performed. We also restrict our sample to workers aged 25 to 55 and exclude workers in public administration and military occupations. Our final

\footnotetext{
${ }^{13} \mathrm{We}$ also explore the threshold of $29^{\circ} \mathrm{C}$ as a robustness check. Precipitation controls in the HDD exercise are the same as in our main exercise (Equation 1).

${ }^{14}$ The panel starts in 2015 because it is the first year that RAIS provides monthly wage data. It ends in 2016 because the daily weather data is available up to that year.
} 
estimation sample has 3,685,235 worker-month observations representing 222,174 workers. ${ }^{15}$

We calculate hourly wages as the ratio between monthly wages and monthly hours of work in the main occupation. ${ }^{16}$ To create a measure of real wages (base month-year is January of 2015), we deflate nominal wages using the Brazilian official consumer price index (IPCA) by month, calculated by the Brazilian Institute of Geography and Statistics (IBGE).

Aside from hourly wages, we also use data on other worker's outcomes, such as: contractual hours per month, days on leave in the month, employment status (permanent vs. temporary) and payment scheme (monthly vs other forms) to investigate possible effects of temperature shocks on employment contracts; data on firm sector, municipality and firm identification of current employment to study labor market mobility; and education (years of schooling) and occupation data to check for heterogeneous effects across workers in occupations more or less dependent on degree of exposure to climate effects.

Table 1 presents descriptive statistics of workers from our estimating sample. The average hourly nominal wage is $13.43 \mathrm{BRL} /$ hour (or approximately $3.32 \mathrm{USD} /$ hour) and the average hourly real wage is 12.35 (or 3.09 USD/hour). ${ }^{17}$ Individuals work on average 43 hours per week in permanent jobs ( $98 \%$ of the sample) and $93 \%$ of them receive monthly wages (instead of weekly or daily). In our sample, workers missed on average 0.33 working days in a month. In regard to education, individuals have on average 11.3 years of schooling ${ }^{18}$ and most are

\footnotetext{
${ }^{15}$ We also lose some workers due to the many levels of fixed effects we include in the analysis. For more details about the sampling process, see section A.1. of the Appendix.

${ }^{16}$ The monthly wage includes labor income, tips, payment for performance, commission fees, additional gratifications from tenure, labor prizes, additional vacation pay, allowances of any kind, value-worked notice, overtime pay or premiums, premium for unhealthy services (even if temporary), food stamps, maternity/paternity leave wage and student scholarships.

${ }^{17}$ Exchange rate was $1 \mathrm{BRL} \approx 0.25 \mathrm{USD}$ on December 31,2015 . Source: International Monetary Fund (IMF).

${ }^{18}$ In Brazil, 12 years of schooling are needed to complete high-school education.
} 
employed in low-skilled sectors (24\%). Only $7 \%$ of the workers are employed in high-skilled occupations. $^{19}$

The table also shows numbers that characterize the panel dimension of the data. Information on wages is available for an average of 16.59 months (out of 24). Wages rose 5.79 times on average in the two-year period, and fell 5.54 times on average over the course of 2015-2016, which may suggest that there is more downward than upward rigidity in wages. We also learn that in the two-year period only $3 \%$ of workers changed municipalities, $4 \%$ changed sector of employment, and 9\% switched employers. These low numbers are not surprising given the short time frame our study covers.

As the majority of our sample of formal workers is employed in permanent jobs, we ask how much monthly wages vary within our two-year time span. Figure 1 shows the distribution of the variation (in \%) of nominal and real wages between consecutive months from January 2015 to December 2016. The left figures consider the full distribution, while the right figure excludes the observations whose wages do not vary. We observe a spike around zero: $30 \%$ of nominal wages do not change and 10\% change very little. Excluding zero variations (right figure), the $10^{t h}$ and $90^{\text {th }}$ percentiles of the distribution are $-20.8 \%$ and $29.9 \%$. These numbers demonstrate that there is a considerable amount of month-to-month variation in nominal wages. The variation in real wages is even larger because monthly inflation rates are always positive over the period we analyze. ${ }^{20}$

We also observe that only a small fraction of the workers in our estimation sample did not

\footnotetext{
${ }^{19}$ We define low-skilled occupations as those in the bottom $25^{\text {th }}$ percentile of the wage and education distributions across all occupations, and high-skilled occupations those in the top $25^{\text {th }}$ of both distributions. In our estimating sample, workers employed in low-skilled occupations have, on average, 9.5 years of schooling, which is elementary school education. Workers on high-skilled occupations have 15.7 years of formal education, or college education.

${ }^{20}$ Kaur (2019) finds similar figures when analyzing Indian labor markets.
} 
Table 1: Sample of employees in the formal labor force

\begin{tabular}{lcc}
\hline \hline & & \\
& Mean & Std. Dev. \\
\hline & & \\
General information & 13.43 & 17.72 \\
Nominal hourly wages (BRL/hour) & 12.35 & 16.24 \\
Real hourly wages (BRL/hour, January of 2015) & 11.26 & 3.07 \\
Years of schooling & 42.76 & 3.43 \\
Contractual hours (per week) & 0.33 & 1.77 \\
Days on leave & 0.98 & \\
Proportion of workers with a permanent job & 0.93 & \\
Proportion of worker that receive a monthly payment & & \\
& & \\
Occupations/Sectors & 0.24 & \\
Proportion of workers with Low Skilled Occupations & 0.07 & \\
Proportion of workers with High Skilled Occupations & & \\
& & \\
Panel information & 0.19 \\
Average number of times workers changed municipality & 0.03 & 0.20 \\
Average number of times workers changed sector & 0.04 & 0.32 \\
Average number of times workers changed employer & 0.09 & 0.32 \\
Average number of months with wage data & 16.59 & 7.52 \\
Average number of times wages rose & 5.79 & 4.11 \\
Average number of times wages fell & 5.54 & 3.60 \\
\hline \hline
\end{tabular}

Notes: Table presents summary statistics of selected variables calculated for the 222,174 workers in our estimation sample. Real hourly wages are in Jan 2015 figures. Data source: RAIS 2015-2016.

experience changes in nominal wages (4,967 workers or $2.2 \%$ ), while workers whose nominal wages changed every month make up $12.9 \%$ of the sample $(28,576$ workers). The deflation of wages naturally "creates" small variations in real wages even when nominal wages were constant, which explains a larger fraction of workers whose real wages changed every month. ${ }^{21}$

\footnotetext{
${ }^{21}$ Appendix Table 1 presents the distribution of workers across the number of times wages changes between two consecutive months from January 2015 to December 2016.
} 

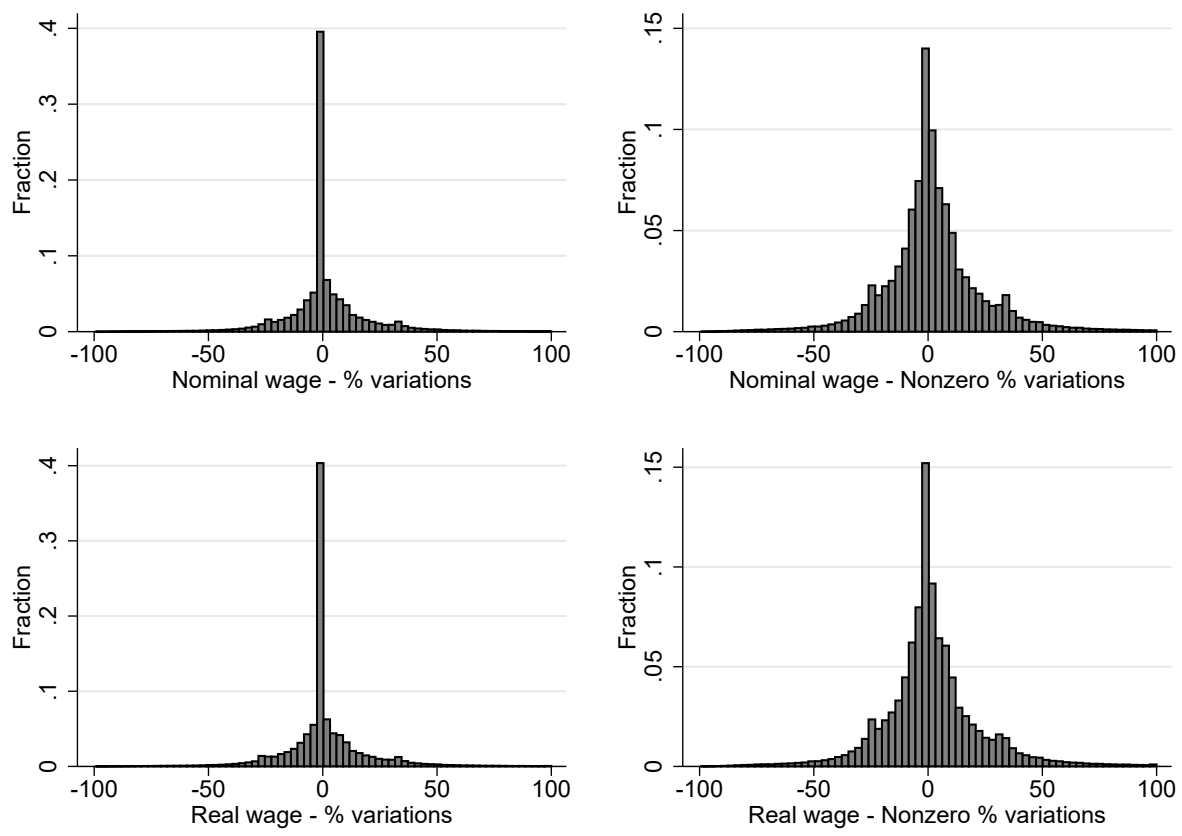

Figure 1: Percentage monthly variation in nominal and real wages

Notes: Figure shows the distribution of percent monthly changes in nominal and real wages for our estimating sample. We calculate changes between consecutive months only, ignoring missing values. Left figures include cases where percent variation in nominal wages are zero, whereas the Right figures exclude those cases. Data source: RAIS 2015-2016

\subsection{Monthly weather data}

To calculate temperature changes by month, we use daily weather data generated by Xavier et al. (2017). ${ }^{22}$ The authors use historical weather observations collected from rain gauges and weather stations from the 'Instituto Nacional de Meteorologia' (INMET), the 'Agência Nacional de Águas' (ANA), and 'Departamento de Águas e Energia Elétrica de São Paulo' (DAEE). Temperature is available for all Brazilian territory starting in January of 1980 and

\footnotetext{
${ }^{22}$ An update of Xavier et al. (2016). The authors compare six different techniques of data interpolation by using data from 3,625 rain gauges (for rainfall) and 735 weather stations (for temperatures). They conclude that the inverse distance weighting and angular distance weighting interpolation techniques are the best way of interpolating stations/rain gauges to the whole Brazilian territory. We use the interpolated data that performed better in their tests.
} 
ending in June of 2017 and precipitation is available from January of 1980 to December of 2016. The spatial resolution of the data is $0.25^{\circ} \times 0.25^{\circ}$, resulting in 27,216 grids.

We convert grid-level data to municipality-level data as follows. For latitude-longitude pairs which fell inside a municipality's boundaries, we consider the municipality weather as the average weather values of those grids. When latitude-longitude pairs did not belong to the municipality polygon, we attribute the closest grid to the municipality centroid within a $0.5^{\circ}(\sim 55 \mathrm{~km})$ range. Based on these assumptions we were able to match weather data for 3,226 municipalities in the country, representing 137 million people, or about $67 \%$ of the country's population in $2015 .^{23}$ In this sense, rural and more remote areas of the country are being excluded from our database as they are distant to weather stations and, therefore, we do not observe their accurate weather data. We believe this is not a problem for estimations as these municipalities usually have small labor markets (particularly for formal workers) and we do not believe weather affects these municipalities differently from larger ones.

After we assign daily grid-level data to each municipality, we calculate monthly averages, Temp $p_{c m t},{ }^{24}$ for our sample years, 2015-2016, by taking a simple mean of the daily observations throughout the month by municipality. We then calculate the long-run average (climate measure) over the 1980-2016 period for each month and municipality, $\bar{T}_{c m}$, so we can construct the variables of Equation (1). ${ }^{25}$ Figure 2 shows the distribution of our main temperature variable, monthly temperature deviations from climate temperatures

\footnotetext{
${ }^{23}$ Our actual estimation sample includes 2,829 municipalities that concentrate 133 million people (65\% of the country's population in 2015), as some small municipalities are excluded when we draw a random sample from our dataset. Appendix Figures 1 and 2 show that the distributions of weather and climate temperature in the full sample (3,226 municipalities) and in our estimation sample (2,829 municipalities) are practically the same.

${ }^{24}$ Temperature in municipality $c$ in month $m$ of year $t$.

${ }^{25}$ We calculate the climate temperature (and precipitation) of month $m$ in a given municipality by taking the average monthly temperature of all $m$ months between 1980 and 2016.
} 
$\left(\Delta T e m p_{c m t}\right)$, after demeaning by municipality fixed effects, municipality and year fixed effects and municipality-year fixed effects. The figure shows we have variation to identify temperature effects on wages even after we incorporate fixed effects. ${ }^{26}$

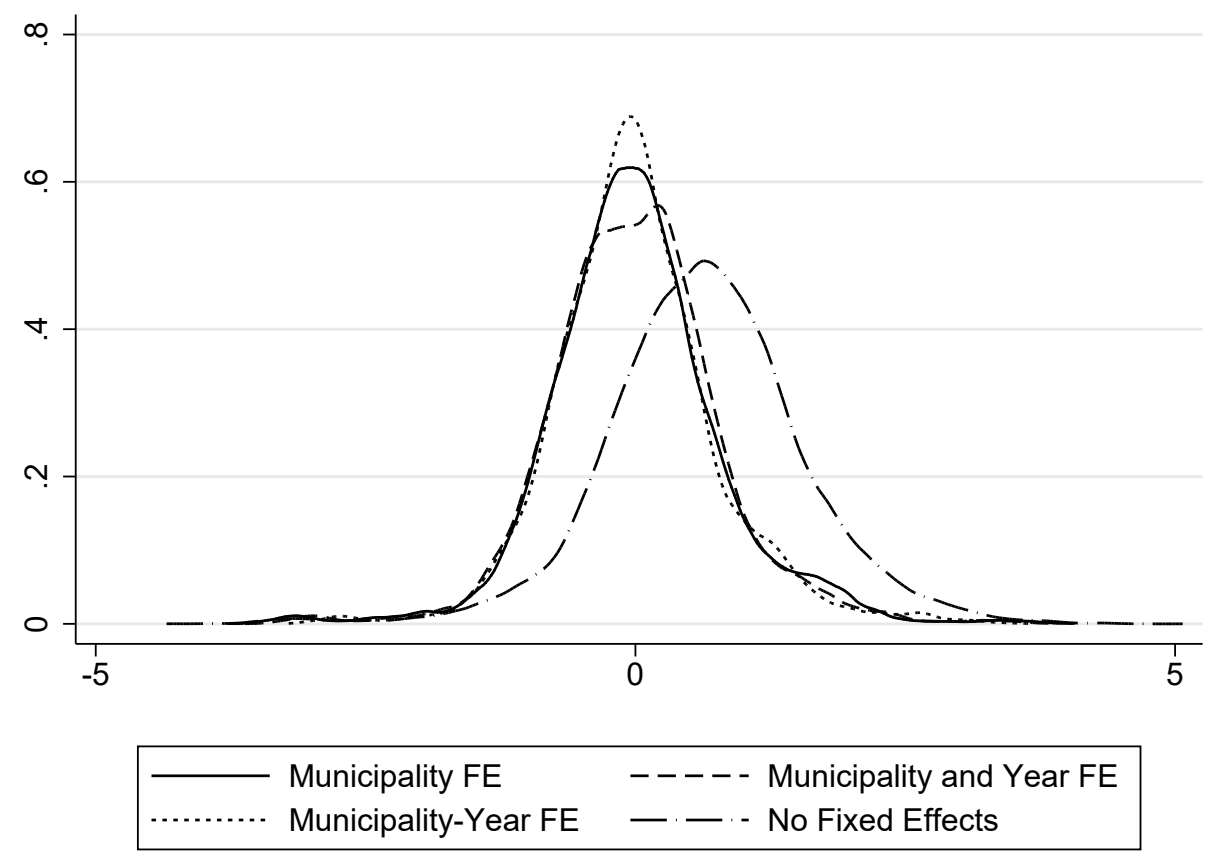

Figure 2: Residual variation in temperature deviations $\left(\Delta T e m p_{c m t}\right)$

Notes: Figure displays the residuals from regressions of $\Delta T e m p_{c m t}$ on municipality fixed effects, municipality and year fixed effects, and municipality-year fixed effects, respectively. The $\Delta T e m p_{c m t}$ itself is also depicted for comparison under the legend "No Fixed Effects". Data source: Xavier et al. (2017), 1980-2016.

Because deviations are calculated as the monthly difference between weather and climate, a negative (positive) value means that the month was colder (hotter) than the monthly climate. Temperature deviations in $2015-2016$ range from $-4^{\circ} \mathrm{C}$ to $+5^{\circ} \mathrm{C}$. Around $98 \%$ of the distribution is concentrated in the $-2^{\circ} \mathrm{C} /+3^{\circ} \mathrm{C}$ interval. Appendix Table 2 and Appendix Figure 3 present further temperature and climate temperature statistics for the municipalities in our estimating sample. The temperature distributions are negatively skewed because most

\footnotetext{
${ }^{26}$ Appendix Table 2 also presents summary statistics for the other weather variables we use in Equation (2), temperature bins, and in Equation (3), Harmful Degree Days (HDD).
} 
of the Brazilian territory is located in Equatorial or Tropical climates. Temperatures between 2015 and 2016 range from $+9^{\circ} \mathrm{C}$ to $+32^{\circ} \mathrm{C}$ and climate normals, calculated from 1980 to 2016 , vary less, from $+12^{\circ} \mathrm{C}$ to $+30^{\circ} \mathrm{C} .{ }^{27}$

\section{Main results}

We begin by presenting estimates of the parameters $\alpha_{1}$ and $\alpha_{2}$ from variants of Equation (1) in Table 2. Each column shows results for different sets of fixed effects. Standard errors are clustered by economic region. ${ }^{28}$ All the results point to the same general pattern: for places and months with lower climate temperatures, deviations form those temperatures are associated with higher hourly wages, whereas for places and month with higher climate temperature, the deviations are associated with lower hourly wages. The fixed effects, however, alter the magnitudes of these effects and also the temperature inflection point. ${ }^{29}$ In particular, comparing columns (1) and (2), we see that adding municipality fixed effects considerably reduces the magnitude of the coefficients. For example, without any fixed effects one would conclude that, for climate temperatures around $30^{\circ} \mathrm{C}$, a one-degree increase in temperature would be associated with nearly $14 \%$ fall in hourly wages, whereas with municipality (and year) fixed effects, the same increase would be associated with a $0.41 \%$ fall in hourly wages.

This sizable discrepancy showcases the importance of accounting for the correlation between

\footnotetext{
${ }^{27}$ Appendix Figures 4 and 5 present temperature bins and HDD distributions, respectively. About $99 \%$ of the HDD distributions lie between $0^{\circ} \mathrm{C}$ and $+45^{\circ} \mathrm{C}$ for the above $29^{\circ} \mathrm{C}$ version and between $0^{\circ} \mathrm{C}$ and $+19^{\circ} \mathrm{C}$ considering above $30^{\circ} \mathrm{C}$. As for the bins, only those three ranging from $+21^{\circ} \mathrm{C}$ to $+30^{\circ} \mathrm{C}$ are not positively skewed since this is the most common temperature range in the sample.

${ }^{28}$ IBGE classifies Brazilian municipalities according to their degree of economic influence, or poles of economic attraction ('Região de Influencia das Cidades' - REGIC). More details available from this link. We cluster the standard errors at the REGIC level.

${ }^{29}$ Temperature inflection point is the average temperature after which the estimated marginal effects of weather shocks change signs, from positive to negative.
} 
temperatures and the determinants of economic activity at the local level. For example, colder municipalities in the country are in the richest South and Southeast regions, whereas the hotter municipalities are in the poorest North and Northeast.

A comparison between the results in columns (2) and (3) reveals further that month fixed effects are relevant to account for the potential correlation between weather and economic seasonality: the association between a one-degree deviation from climate temperatures at $30^{\circ} \mathrm{C}$ more than doubles $(-0.41 \%$ to $-0.95 \%)$. This could reflect, for example, that labor markets are normally more active during warmer seasons because of the holidays in the Southern hemisphere (e.g. Christmas, New Year's eve and Carnival happen during summer). In that case, the estimates without month fixed effects would be understating the effect of temperature on wages at high climate temperatures.

The results from columns (4) through (6) show that adding firm and individual fixed effects makes little difference in the magnitudes of the estimates, suggesting that bias stemming from changes in the composition of jobs and workforce plays a limited role in our context. We cannot state, however, that composition bias is not a potential threat to identification of weather-economic relationships in general. We believe that it is particular to our setting because we are capturing short-term relationships, and there are very few observed moves in and out of jobs and municipalities from month to month in the period we analyze.

We present our preferred estimates in column (7), which reflect the whole set of fixed effects highlighted in Equation (1). Figure 3 shows marginal effects across different levels of climate temperatures. At climate temperatures below $16^{\circ} \mathrm{C}$, one-degree deviations have a positive but modest effect on hourly wages. ${ }^{30}$ For temperatures above $18^{\circ} \mathrm{C}$, the signs

\footnotetext{
${ }^{30}$ The effects we find using worker-level data are consistent with macro-level studies that find positive
} 
reverse. Between $24^{\circ} \mathrm{C}$ and $30^{\circ} \mathrm{C}$, the marginal effects range from $-0.53 \%$ to $-0.96 \%$. To put this effect in perspective, the average monthly deviation in that temperature range for year 2015 in our dataset is $0.83^{\circ} \mathrm{C}$. That would correspond to a $-0.44 \%$ (and $-0.8 \%$ ) effect on wages attributed to monthly weather shocks at $24^{\circ} \mathrm{C}\left(30^{\circ} \mathrm{C}\right)$ average temperatures. ${ }^{31}$

We now use our results to provide a measure of the average income losses from a sustained $1^{\circ} \mathrm{C}$ shock in all months of the year 2015 . First, we calculate the predicted wage change for each worker in our sample based on the results from column (7), Table 2, and average it over the months. Real hourly wages, then, fall by $0.42 \%$. To provide an annual measure of the total income losses, we add the monthly predicted changes in real monthly wages across all months within our estimating sample, and arrive at in-sample losses of $\mathrm{R} \$ 17,854,976$ (US $\$$ $4,463,744)$ for the year 2015. Expanding these losses to the 56.5 million workers that make up Brazil's formal labor markets corresponds to nearly $\mathrm{R} \$ 4.5$ billion in real income losses. That is equivalent to US\$ 1.1 billion, or $0.06 \%$ of the GDP. ${ }^{32}$

We repeat the exercise described above but now assuming that the climate temperatures (that is, $\bar{T}_{c m}$ ) have uniformly increased by $2^{\circ} \mathrm{C}$ to reflect climate change predictions (Guivarch and Hallegatte, 2013; Kwok et al., 2018). We conclude that under that scenario, real hourly wage would be $2.04 \%$ lower. Calculated for our estimating sample, the losses in annual income would amount to $\mathrm{R} \$ 85,971,712$ (US\$ 21,492,928). Applying these losses to the universe of formal workers would lead to $\mathrm{R} \$ 21.9$ billion in annual income losses. This figure effect (or null effect) on income of an increase of $1^{\circ} \mathrm{C}$ in colder countries (Dell et al., 2012; Burke et al., 2015).

${ }^{31}$ Our numbers are still lower (in module) than the findings in the literature when assessing a $1^{\circ} \mathrm{C}$ increase in temperatures on industrial output (Hsiang, 2010; Zhang et al., 2018; Chen and Yang, 2019) and on income in poor countries (Dell et al., 2012; Burke et al., 2015) or warmer seasons in the U.S. (Deryugina and Hsiang, 2014).

${ }^{32}$ Brazilian GDP in 2015 was US\$ 1.8 trillion. Source: World Bank. 
corresponds to US\$ 5.5 billion, or $0.30 \%$ of the GDP in 2015.

Table 2: Temperature shocks and real hourly wages

\begin{tabular}{|c|c|c|c|c|c|c|c|}
\hline & $(1)$ & (2) & $(3)$ & (4) & (5) & (6) & (7) \\
\hline$\overline{\Delta T e m p}$ & $\begin{array}{c}0.23235^{* * *} \\
(0.06769)\end{array}$ & $\begin{array}{l}0.00790^{* *} \\
(0.00346)\end{array}$ & $\begin{array}{l}0.01212^{* * *} \\
(0.00231)\end{array}$ & $\begin{array}{l}* 0.01045^{* * *} \\
(0.00202)\end{array}$ & $\begin{array}{l}{ }^{*} 0.01104^{* * *} \\
(0.00194)\end{array}$ & $\begin{array}{l}{ }^{*} 0.01092^{* * * *} \\
(0.00198)\end{array}$ & $\begin{array}{l}0.01192^{* * *} \\
(0.00146)\end{array}$ \\
\hline$(\Delta T e m p) \cdot \bar{T}$ & $\begin{array}{l}-0.01228^{* * *} \\
(0.00325)\end{array}$ & $\begin{array}{c}{ }^{*}-0.00040 * * \\
(0.00017)\end{array}$ & $\begin{array}{l}-0.00072^{* * *} \\
(0.00010)\end{array}$ & $\begin{array}{c}{ }^{*}-0.00062^{* * *} \\
(0.00009)\end{array}$ & $\begin{array}{c}{ }^{*}-0.00066^{* * *} \\
(0.00009)\end{array}$ & $\begin{array}{c}{ }^{*}-0.00065^{* * *} \\
(0.00009)\end{array}$ & $\begin{array}{c}{ }^{*}-0.00072^{* *} \\
(0.00007)\end{array}$ \\
\hline R-squared & 0.00607 & 0.00002 & 0.00003 & 0.00008 & 0.00024 & 0.00027 & 0.00032 \\
\hline Obs. & $3,685,235$ & $3,685,235$ & $3,685,235$ & $3,685,235$ & $3,685,235$ & $3,685,235$ & $3,685,235$ \\
\hline Workers & 222,174 & 222,174 & 222,174 & 222,174 & 222,174 & 222,174 & 222,174 \\
\hline Mean of dep. var. & 13.34 & 13.34 & 13.34 & 13.34 & 13.34 & 13.34 & 13.34 \\
\hline Temp. Inv. $\left({ }^{\circ} \mathrm{C}\right)$ & 18.9 & 19.7 & 16.8 & 16.8 & 16.8 & 16.8 & 16.6 \\
\hline Worker FE & No & No & No & No & Yes & Yes & Yes \\
\hline Firm FE & No & No & No & Yes & No & Yes & Yes \\
\hline Municipality FE & No & Yes & Yes & Yes & Yes & Yes & No \\
\hline Year FE & No & Yes & Yes & Yes & Yes & Yes & No \\
\hline Month FE & No & No & Yes & Yes & Yes & Yes & Yes \\
\hline Municipality-Year FE & No & No & No & No & No & No & Yes \\
\hline
\end{tabular}

Notes: Table shows estimates of versions of Equation (1) for different sets of fixed effects. Dependent variable is the $\log$ of real hourly wages. Wages are monthly deflated for January, 2015. Temperature is included in the model as deviations from climate temperature $(\Delta T e m p)$ and its interaction with climate temperature $((\Delta T e m p) \cdot \bar{T})$. All regressions include precipitation variables as controls and standard errors are clustered by economic region. "Temp. Inv. $\left({ }^{\circ} \mathrm{C}\right)$ " is the temperature inflection point, which is the $\bar{T}$ that makes $\frac{\partial}{\Delta T e m p}\left[\hat{\alpha}_{1} \Delta T e m p+\hat{\alpha}_{2}(\Delta T e m p) \cdot \bar{T}\right]=0$. Data sources: labor market data from RAIS 2015-2016 and weather data from Xavier et al. (2017).

In what follows, we ask if our main results stand when we employ alternative specifications for weather shocks. Figure 4 presents estimates from temperature bins described in Equation (2). These results confirm our main findings: extreme hot temperatures have adverse effects on wages. More specifically, an additional day in the month that falls in the above $30^{\circ} \mathrm{C}$ bin, instead of the $21-24^{\circ} \mathrm{C}$ bin, results in a $0.1 \%$ reduction in hourly wages; an additional day in the $27-30^{\circ} \mathrm{C}$ bin also has a negative effect on wages, although much smaller, $0.05 \%$. It is worth pointing out that increases in the number of days in lower temperature bins could have a modest adverse impact on wages, although the evidence is not conclusive given that the coefficients are not statistically significant. 

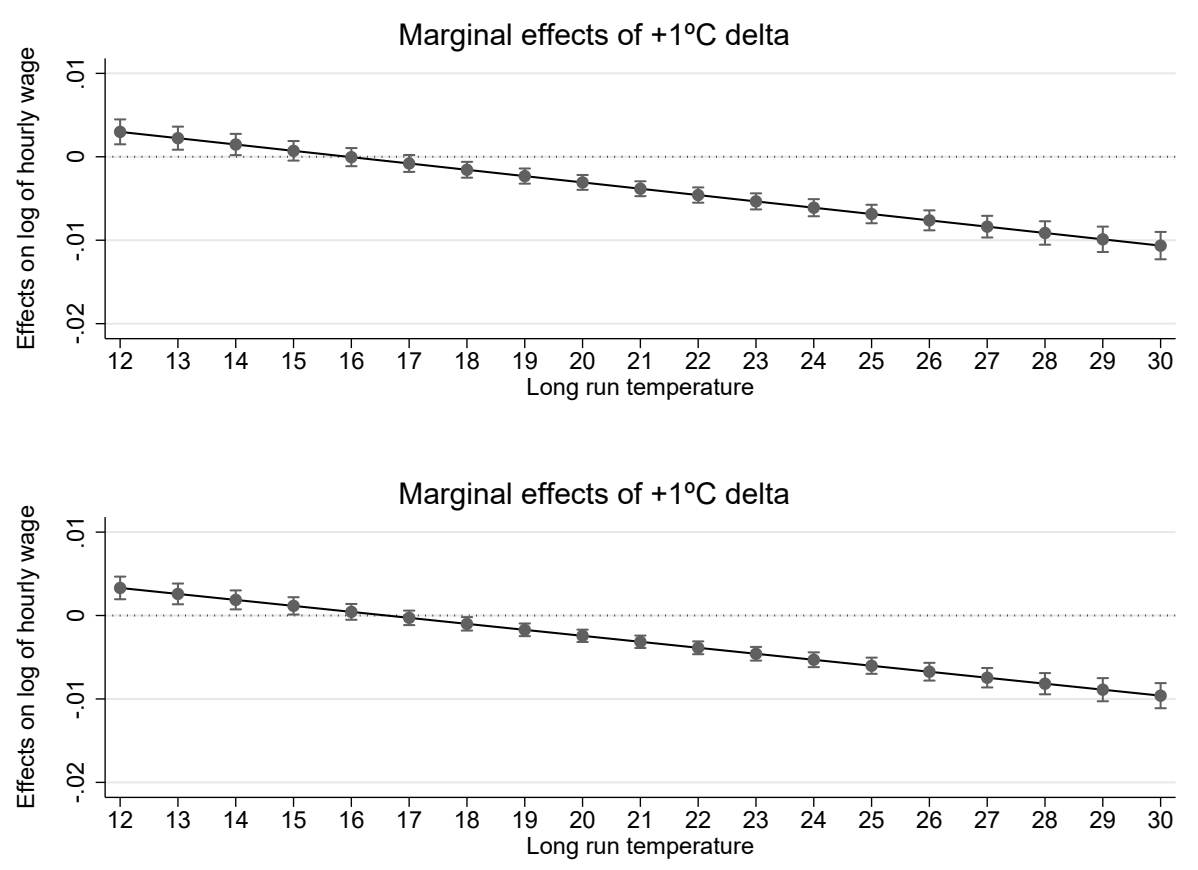

Figure 3: Marginal effects of $1^{\circ} \mathrm{C}$ shock on log of real hourly wages

Notes: Figures show marginal effects of $1^{\circ} \mathrm{C}$ temperature shock on the log of real hourly wages for different levels of climate temperature $(\bar{T})$. Top figure refers to column 3 of Table 2, which uses municipality, year and month fixed effects. The bottom figure refers to column 7 of Table 2, which adds worker and firm fixed effects and swaps municipality and year by municipality-year fixed effects. Data sources: labor market data from RAIS 2015-2016 and weather data from Xavier et al. (2017).

Finally, in Table 3 we attempt to capture the impact of extremely hot temperatures using $\mathrm{HDD}$, the number of degree-days with temperatures above $30^{\circ} \mathrm{C}$. We also present results for the $29^{\circ} \mathrm{C}$ threshold. Once again, the estimates confirm our previous findings. An additional degree-day above $30^{\circ} \mathrm{C}$ results in hourly wages $0.047 \%$ lower; the effect is somewhat smaller if we consider the $29^{\circ} \mathrm{C}$ threshold: a $0.033 \%$ reduction.

Overall, the evidence from three different weather specifications indicates that hourly wages are negatively impacted by extreme (mostly hot) temperatures. In the sections that follow, we investigate the possible mechanisms connecting short-term changes in temperature and wages in Brazil. 


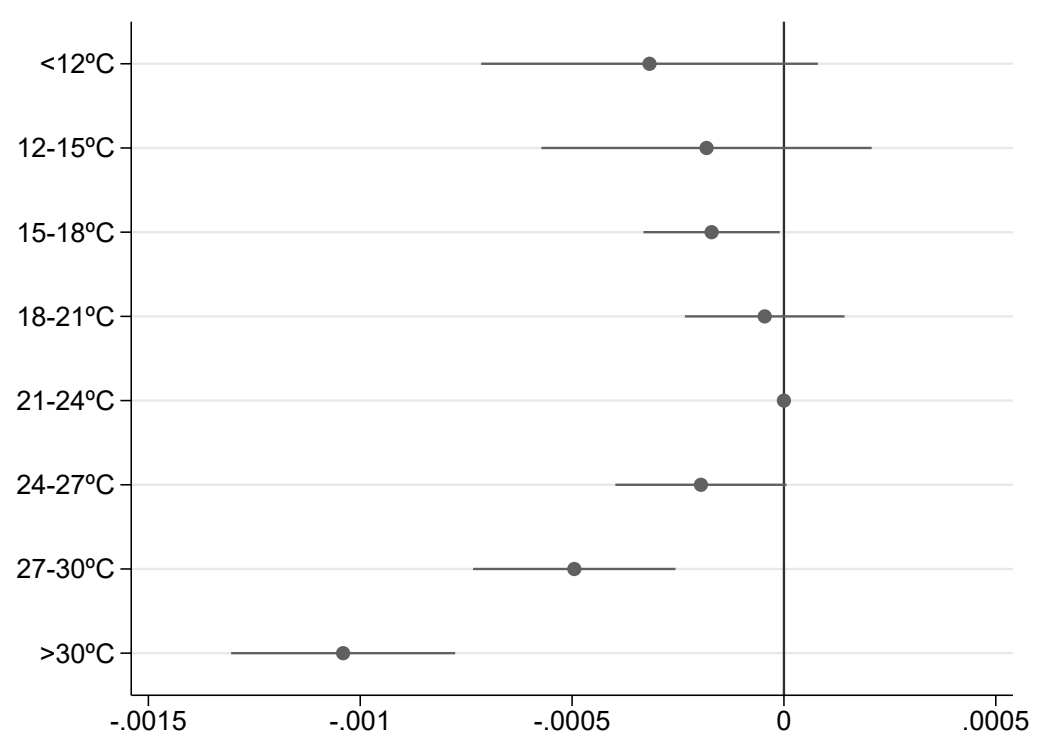

Figure 4: Temperature shocks and real hourly wages, alternative specification Temperature Bins

Notes: Figure shows estimates from Equation 2. We use our preferred specification, which includes worker, firm, month and municipality-year fixed effects. Temperature bins range from below $12^{\circ} \mathrm{C}$ to above $30^{\circ} \mathrm{C}$ in sets of $3^{\circ} \mathrm{C}$. The $21-24^{\circ} \mathrm{C}$ bin is the base category. Regression includes precipitation bins as controls and standard errors are clustered by economic region. Appendix Table 3 shows the estimation results. Data sources: labor market data from RAIS 2015-2016 and weather data from Xavier et al. (2017).

\section{Nominal wages and employment contracts}

One plausible explanation for the effects we see on hourly wages is that workers and firms engage in a (implicit) risk-sharing labor arrangement whereby workers accept temporary reductions in nominal wages to avoid layoffs when faced with short-term labor demand shocks (Franklin and Labonne, 2019). ${ }^{33}$ Therefore, motivated by a literature that studies labor market responses to environmental shocks (Dell et al., 2014; Franklin and Labonne, 2019; Kaur, 2019), we ask if short-term temperature shocks impact nominal wages in Brazil's formal urban labor markets.

\footnotetext{
${ }^{33}$ The premise is that extreme temperatures have an adverse impact on workers' productivity. Recent studies using data from the manufacturing sector have established the link between temperatures and worker output in China (Cai et al., 2018) and India (Bangalore) (Adhvaryu et al., 2020).
} 
Table 3: Temperature shocks and real hourly wages, alternative specification - Harmful Degree Days (HDD)

\begin{tabular}{lcc}
\hline \hline & $\begin{array}{c}(1) \\
\text { Log of hourly wage }\end{array}$ & $\begin{array}{c}(2) \\
\text { Log of hourly wage }\end{array}$ \\
\hline HDD 30+ & $-0.00047^{* * *}$ & \\
& $(0.00010)$ & \\
HDD 29+ & & $-0.00033^{* * *}$ \\
& & $(0.00006)$ \\
\hline R-squared & 0.00009 & 0.00011 \\
Obs. & $3,685,235$ & $3,685,235$ \\
Workers & 222,174 & 222,174 \\
Mean of dep. var. & 13.34 & 13.34 \\
Worker FE & Yes & Yes \\
Firm FE & Yes & Yes \\
Month FE & Yes & Yes \\
Municipality-Year FE & Yes & Yes \\
\hline \hline
\end{tabular}

Notes: Table shows estimates from Equation 3. We use our preferred specification, which includes worker, firm, month and municipality-year fixed effects. Regressions include precipitation variables as controls (same functional form as in Equation 1) and standard errors are clustered by economic region. Data sources: labor market data from RAIS 2015-2016 and weather data from Xavier et al. (2017).

We estimate the parameters from Equation (1) for nominal wages and show the results in Figure 5. The observed pattern in the temperature-wage relationship resembles the one in Figure 3 where we used real wages. The magnitudes of the effects, however, are about half the size. Results using temperature bins and HDD yield the same conclusions: while the estimates of the effects of extreme hot temperatures on nominal wages are negative and significant, they are also smaller in magnitude than the ones we see for real wages. (See Appendix Figure 6 and Appendix Table 4.)

Next, we ask if these shocks had an effect on employment outcomes. The RAIS dataset allows us to look at contractual hours, days on leave, the incidence of permanent employment contracts and payment schemes (monthly payments vs other forms). ${ }^{34}$ We present the

\footnotetext{
${ }^{34}$ Other forms of payment scheme take on value zero, and they comprise the categories weekly, hourly,
} 

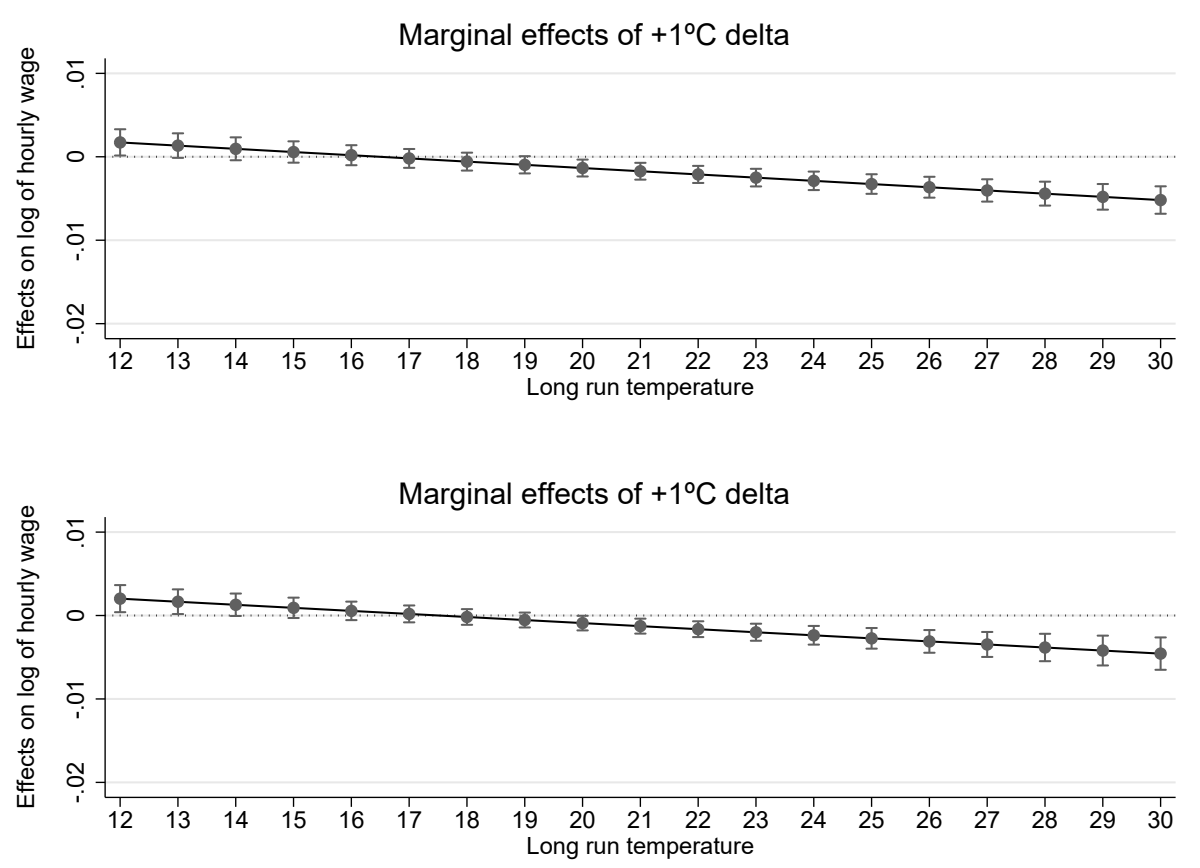

Figure 5: Marginal effects of $1^{\circ} \mathrm{C}$ shock on log of nominal hourly wages

Notes: Figures show marginal effects of $1^{\circ} \mathrm{C}$ temperature shock on the log of nominal hourly wages for different levels of climate temperature $(\bar{T})$. Top figure refers to column 3 of Appendix Table 5 , which uses municipality, year and month fixed effects. The bottom figure refers to column 7 of Appendix Table 5 , which adds worker and firm fixed effects and swaps municipality and year by municipality-year fixed effects. Data sources: labor market data from RAIS 2015-2016 and weather data from Xavier et al. (2017).

results in Table 4 . We find no significant effects on contractual hours and other employment outcomes. $^{35}$

Taken together, these results suggest that nominal wages indeed adjust in response to transitory temperature shocks in Brazil's formal labor markets, and that changes in wages may be the main adjustment mechanism available to deal with such shocks since we find no effect on other employment outcomes. In the next section, we turn our investigation to the composition channel.

bi-weekly, daily, and by task ("tarefa"). Note that $93 \%$ of the sample work under a monthly payment scheme, indicating that this is the major payment scheme prevailing in Brazil's formal non-agriculture labor markets. See Appendix A.2. for more information on these outcomes.

${ }^{35}$ While we do not have data on layoffs from RAIS, we use an indicator for whether the worker left our sample as a proxy for leaving the formal labor market. We also find no effect on this outcome. 
Table 4: Temperature shocks and employment outcomes

\begin{tabular}{lcccc}
\hline \hline & Log hours & Days on leave & Permanent job & Monthly payment \\
\hline$\Delta$ Temp & 0.00005 & -0.01560 & -0.00006 & 0.00008 \\
& $(0.00006)$ & $(0.01110)$ & $(0.00008)$ & $(0.00007)$ \\
$(\Delta$ Temp $) \bar{T}$ & -0.00000 & 0.00090 & 0.00000 & -0.00000 \\
& $(0.00000)$ & $(0.00057)$ & $(0.00000)$ & $(0.00000)$ \\
\hline R-squared & -0.00000 & 0.00000 & -0.00000 & -0.00000 \\
Obs. & $3,685,235$ & $3,685,235$ & $3,685,235$ & $3,685,235$ \\
Workers & 222,174 & 222,174 & 222,174 & 222,174 \\
Mean of dep. var. & 3.75 & 0.30 & 0.98 & 0.92 \\
Worker FE & Yes & Yes & Yes & Yes \\
Firm FE & Yes & Yes & Yes & Yes \\
Month FE & Yes & Yes & Yes & Yes \\
Municipality-Year FE & Yes & Yes & Yes & Yes \\
\hline \hline
\end{tabular}

Notes: Log hours in the log of contractual working hours, Days on leave is the number of days worker is on leave of absence, Permanent job is an indicator for whether the worker is in a permanent employment contract (zero if temporary), Monthly payment is an indicator for whether payment is received on monthly basis (zero if weekly, daily, biweekly, hourly or piece rate). All regressions include precipitation variables as controls and standard errors are clustered by economic region. Data sources: labor market data from RAIS 2015-2016 and weather data from Xavier et al. (2017).

\section{Composition effects}

We turn to another relevant mechanism leading to wage effects from temperature shocks:

jobs and labor force composition. Most analyses based on aggregate-level data do not deal with the possibility that weather shocks alter the types of jobs and workers that are observed in a given locality at a certain period of time, especially studies relying on annual data where economic agents have more time to adapt to changes. If individuals react to environmental shocks by migrating in and out of localities, or switching jobs and sectors, an empirical relationship between (nominal and real) wages and temperature may not be attributed to causal direct productivity impacts only, but also to changes in workforce skill composition, both observed and unobserved, or sectoral mix. 
Because we have a panel of workers and observe them when they change firms, sectors, or municipality, we examine further if temperature shocks lead to such changes. ${ }^{36}$ We present the results in Table 5. We use the temperature shock from the previous month to account for the fact that these transitions are less likely to be made based on current weather changes. We find evidence suggesting movement across sectors and firms, in patterns consistent with what we find for wages.

We do not believe, however, that these changes explain the wage effects we find for two reasons. First, the percent of workers that changed sector or firms within the period we study is very small (4\% and 9\%). Second, and more importantly, the estimates with and without worker and firm fixed effects we present in Table 2 differ very little.

To make this point clearer, in Appendix Table 6, column (2), we present further results obtained after removing from the sample workers that have changed cities, firm, or sectors at any time during the period we study. We show that the results are virtually the same as our main estimates, which we present in column (1), suggesting that these transitions are not driving our results. Finally, to check if movements of workers in and out of formal labor markets explain our findings, we compare our main estimates with those obtained for a balanced sample consisting of workers that never left our sample in Appendix Table 6, column (3). Again, the results change very little. We take this as suggestive evidence that these transitions have little role in the estimated temperature-wage relationship.

\footnotetext{
${ }^{36}$ See Appendix A.2. for more information on these outcomes.
} 
Table 5: Temperature shocks and labor market movements

\begin{tabular}{lcccc}
\hline \hline & Municipality & Sector & Firm & Out Lab. Market \\
\hline$\Delta$ Temp & -0.00027 & $-0.00056^{* * *}$ & $-0.00094^{* *}$ & -0.00155 \\
& $(0.00027)$ & $(0.00021)$ & $(0.00040)$ & $(0.00406)$ \\
$(\Delta$ Temp $) . \bar{T}$ & 0.00001 & $0.00003^{* * *}$ & $0.00006^{* * *}$ & -0.00018 \\
& $(0.00001)$ & $(0.00001)$ & $(0.00002)$ & $(0.00018)$ \\
\hline R-squared & 0.00001 & 0.00001 & 0.00003 & 0.00021 \\
Obs. & $3,511,917$ & $3,511,917$ & $3,511,917$ & $5,037,827$ \\
Workers & 218,229 & 218,229 & 218,229 & 227,225 \\
Mean of dep. var. & 0.001 & 0.002 & 0.005 & 0.301 \\
Worker FE & Yes & Yes & Yes & Yes \\
Firm FE & Yes & Yes & Yes & Yes \\
Month FE & Yes & Yes & Yes & Yes \\
Municipality-Year FE & Yes & Yes & Yes & Yes \\
\hline \hline
\end{tabular}

Notes: Municipality is an indicator for whether the worker changes municipalities; Sector is an indicator for changing sector of employment, Firm is an indicator for changing firms; Out Lab. Market is an indicator for whether the worker has left the sample (the outcome variable takes on value 1 if worker is in the sample, and 0 if worker was in sample in previous months but no longer is in that month). All regressions include precipitation variables as controls and standard errors are clustered by economic region. Data sources: labor market data from RAIS 2015-2016 and weather data from Xavier et al. (2017).

\section{$7 \quad$ Heterogeneous effects}

Finally, we ask the following question: Could the wage effects we estimate be explained by the relationship between temperature and labor productivity? A large and well-established body of research conclude that extreme cold and hot temperatures are detrimental to worker productivity, with tasks such as attention, vigilance, and mental arithmetic being adversely affected (Ramsey, 1995; Pilcher et al., 2002; Seppänen et al., 2006). Recently, studies employing short-term weather and actual output production data from manufacturing sector in developing countries find direct evidence of the negative consequences of hot temperatures for worker productivity (Cai et al., 2018; Adhvaryu et al., 2020). Thus, if workers are less 
productive when exposed to harmful heat levels, real wages would fall.

Our main challenge is that, unlike the aforementioned studies, we do not have a direct measure of worker output. While we cannot provide direct evidence for this channel, we attempt to do so indirectly. The idea is to classify workers according to their likely exposure to a non-climate-controlled working environment based on information about their occupation (Zivin and Neidell, 2014; Behrer and Park, 2017; Zhang et al., 2018). But instead of choosing the occupations arbitrarily, we opt for using information on the distribution of wages and education across occupations. The occupations in the bottom 25th percentile of wage and education are classified as "exposed" to weather and climate, whereas those in the top 25th percentile of wage and education are classified as "less exposed". ${ }^{37}$

We present the results in Figure $6{ }^{38}$ We find that the wages of workers in high skilled occupations (less exposed) do not respond to temperature increases, whereas the wage of workers in low skilled occupations (exposed) do. The difference in the estimated effects between the two groups is statistically different starting at a $22^{\circ} \mathrm{C}$ climate temperature.

We take these finding as suggestive (indirect) evidence of the labor productivity mechanism, assuming that workers in the low skilled occupations are more likely to perform their jobs outdoors or in non-climate-controlled indoor environments. It is plausible, however, that the explanation for these results is differences in labor market mobility (leading to stronger composition effects amongst low-skilled occupations) or in adjustment to employment contracts among the two groups. The evidence, however, does not point in that direction. (See

\footnotetext{
${ }^{37}$ We first take the average years of schooling and hourly wages within each occupation. Then we calculate the 25th and 75th percentile of the distribution of years of schooling and hourly wages to classify each occupation. We disregard the ones between the 25th and 75 th percentiles. See Appendix Table 7 for a list of occupations in each of the categories. We use around 600 occupations for our empirical exercise. They are summarized in about 100 broader categories in the table.

${ }^{38}$ Appendix Table 8 shows the estimates.
} 
Appendix Tables 9 and 10.)

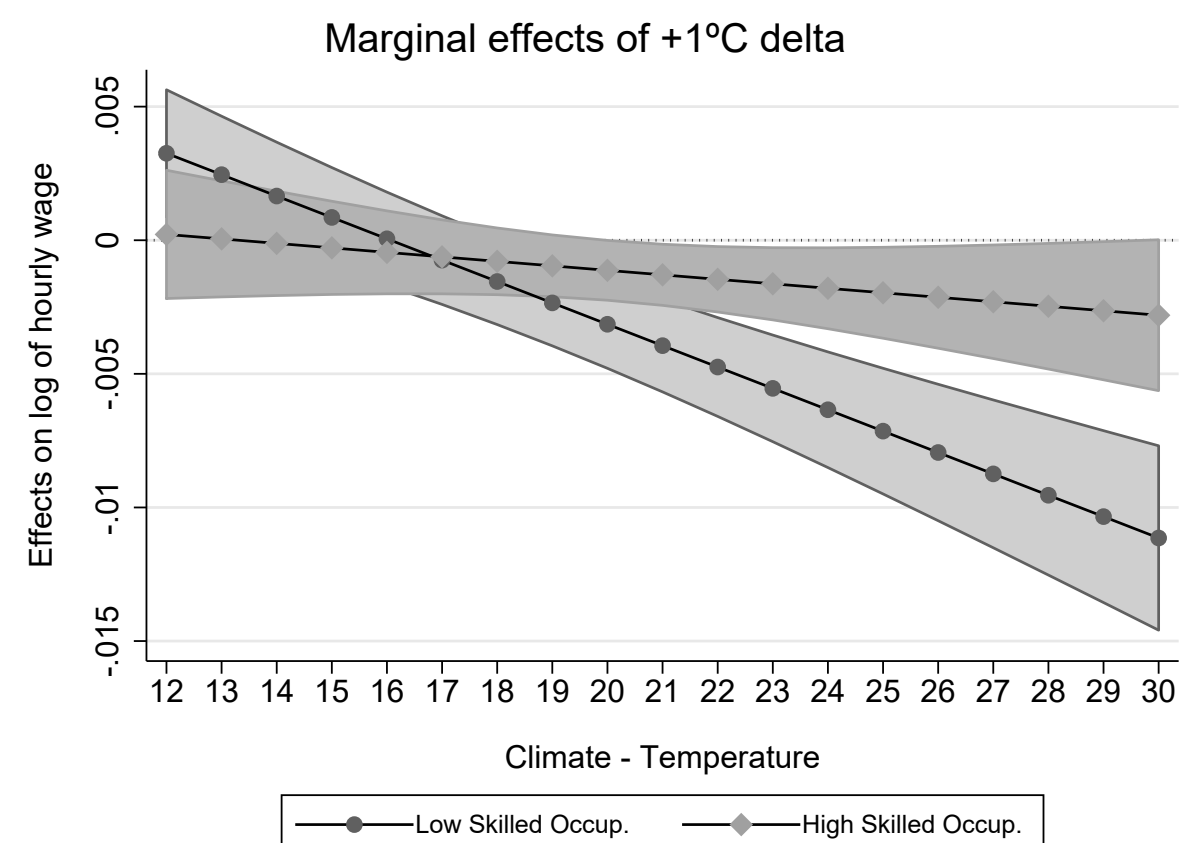

Figure 6: Marginal effects of $1^{\circ} \mathrm{C}$ shock on log of real hourly wage - Exposed vs less exposed occupations

Notes: Figure shows marginal effects of $1^{\circ} \mathrm{C}$ temperature shock on the log of real hourly wages for different levels of climate temperature $(\bar{T})$. Effects are separated for Low Skilled Occupations and High Skilled Occupations. Low Skilled Occupations are defined as the bottom 25th percentile of the occupation wage and education distributions, High Skilled Occupations the top 25th. Regressions also include precipitation variables as controls and standard errors are clustered by economic region. A version of this exercise using nominal wages is presented in Appendix Figure 7. Data sources: labor market data from RAIS 2015-2016 and weather data from Xavier et al. (2017).

\section{Final remarks}

This paper employs individual-level panel data and exploits monthly variations in weather to study whether and how wages respond to short-term temperature shocks that potentially affect worker's productivity. Our main conclusion is that there are positive effects in colder climates, but negative effects in warmer climates. This inverse U-shaped result echoes 
the findings from some studies using cross-country comparisons, and firm-level output and worker's actual productivity data.

We are able to draw some relevant insights from our analysis. Because Brazil's warmer North and Northeast regions are the poorest, weather vulnerability might deepen the existing south-north inequality. Furthermore, the negative effect on wages in warmer climates outweighs the positive impact in colder climates, suggesting that average income losses may be larger as future climate becomes warmer if no adaptation occurs. Finally, we find effects for exposed, low-skilled, occupations but not for less-exposed ones. Thus, workplace susceptibility to temperature shocks may also create further disparities in incomes.

It is worth noting that because of data limitations, our analysis is restricted to formalsector workers, leaving out around $40 \%$ of Brazil's labor force that is employed in the informal sector. We believe, however, that this omission leads us to understate the adverse wage effects of elevated temperature, as informal workers are likely to be more vulnerable to weather shocks.

\section{References}

Adhvaryu, A., Kala, N., and Nyshadham, A. (2020). The Light and the Heat: Productivity Co-benefits of Energy-saving Technology. Review of Economics and Statistics, 0034-6535, 1-36.

Araújo, P. H. C., Silva, F. D. F., Gomes, M. F. M., Féres, J. G., and Braga, M. J. (2014). An analysis of the impact of climate change on agricultural productivity of Northeast of Brazil. Rev. Econ. NE, 45(3), 46-57. 
Assad, E. D., Martins, S. C., Beltrão, N. E. d. M., and Pinto, H. S. (2013). Impacts of climate change on the agricultural zoning of climate risk for cotton cultivation in Brazil. Pesq. agropec. bras., 48(1), 1-8.

Assad, E. D., Pinto, H. S., Zullo, J., Maria, A., and Ávila, H. (2004). Climatic changes impact in agroclimatic zonning of coffee in Brazil. Pesq. agropec. bras., 39(11), $1057-1064$.

Banerjee, R. and Maharaj, R. (2020). Heat, infant mortality, and adaptation: Evidence from india. Journal of Development Economics, 143, 102378.

Barbarisi, B., Marin, F. R., Assad, E. D., Pilau, F. G., and Pacheco, L. (2007). Efeito das mudanças climáticas sobre a aptidão climática para cana-de-açúcar no estado de Goiás. In XV Congresso Brasileiro de Agrometeorologia, pages 1-5.

Barreca, A., Clay, K., Deschênes, O., Greenstone, M., and Shapiro, J. S. (2015). Convergence in adaptation to climate change: Evidence from high temperatures and mortality, 1900-2004. American Economic Review, 105(5), 247-51.

Barreca, A., Clay, K., Deschenes, O., Greenstone, M., and Shapiro, J. S. (2016). Adapting to climate change: The remarkable decline in the us temperature-mortality relationship over the twentieth century. Journal of Political Economy, 124(1), 105-159.

Barreca, A. I. (2012). Climate change, humidity, and mortality in the united states. Journal of Environmental Economics and Management, 63(1), 19-34.

Behrer, A. P. and Park, J. (2017). Will we adapt? temperature, labor and adaptation to climate change. Working Paper, p. 1-39. 
Burgess, R., Deschenes, O., Donaldson, D., and Greenstone, M. (2017). Weather, climate change and death in india. Working Paper, p. 1-71.

Burke, M., Hsiang, S. M., and Miguel, E. (2015). Global non-linear effect of temperature on economic production. Nature Research Letter, 527, 16.

Butler, E. E. and Huybers, P. (2013). Adaptation of us maize to temperature variations. Nature Climate Change, 3(1), 68-72.

Butler, E. E. and Huybers, P. (2015). Variations in the sensitivity of US maize yield to extreme temperatures by region and growth phase. Environmental Research Letters, 10(3), 034009.

Cai, X., Lu, Y., and Wang, J. (2018). The impact of temperature on manufacturing worker productivity: evidence from personnel data. Journal of Comparative Economics, 46(4), 889-905.

Castro, N. R., Spolador, H. F. S., and Marin, F. R. (2019). Assessing the economyclimate relationships for brazilian agriculture. Empirical Economics, 1435-8921, 1-28.

Chen, X. and Yang, L. (2019). Temperature and industrial output: Firm-level evidence from China. Journal of Environmental Economics and Management, 95(2019), 257-274.

Colmer, J. (2020). Weather, labor reallocation and industrial production: evidence from india. Working Paper, p. 1-128.

Dell, M., Jones, B. F., and Olken, B. A. (2012). Temperature shocks and economic 
growth: Evidence from the last half century. American Economic Journal: Macroeconomics, 4(3), 66-95.

Dell, M., Jones, B. F., and Olken, B. A. (2014). What Do We Learn from the Weather? The New Climate-Economy Literature. Journal of Economic Literature, 52(3), 740-798.

Deryugina, T. and Hsiang, S. M. (2014). Does the Environment Still Matter? Daily Temperature and Income in the United States. Working Paper, p. 1-47.

Deschenes, O. (2014). Temperature, human health, and adaptation: A review of the empirical literature. Energy Economics, 46, 606-619.

Deschenes, O. and Greenstone, M. (2007). The Economic Impacts of Climate Change : Evidence from Agricultural Output and Random Fluctuations in Weather. The American Economic Review, 97(1), 354-385.

Deschenes, O. and Greenstone, M. (2011). Climate Change, Mortality, and Adaptation: Evidence from Annual Fluctuations in Weather in the US. American Economic Journal: Applied Economics, 3(4), 152-85.

Feng, S., Krueger, A. B., and Oppenheimer, M. (2010). Linkages among climate change, crop yields and Mexico-US cross-border migration. Proceedings of the National Academy of Sciences, 107(32), 14257-14262.

Franklin, S. and Labonne, J. (2019). Economic shocks and labor market flexibility. Journal of Human Resources, 54(1), 171-199. 
Guivarch, C. and Hallegatte, S. (2013). 2c or not 2c? Global Environmental Change, 23(1), 179-192.

Hsiang, S. M. (2010). Temperatures and cyclones strongly associated with economic production in the Caribbean and Central America. Proceedings of the National Academy of Sciences, 107(35), 15367-15372.

Jacob, B., Lefgren, L., and Moretti, E. (2007). The dynamics of criminal behavior evidence from weather shocks. Journal of Human resources, 42(3), 489-527.

Jayachandran, S. (2006). Selling labor low: Wage responses to productivity shocks in developing countries. Journal of political Economy, 114(3), 538-575.

Jessoe, K., Manning, D. T., and Taylor, J. E. (2018). Climate change and labour allocation in rural mexico: Evidence from annual fluctuations in weather. The Economic Journal, 128(608), 230-261.

Kaur, S. (2019). Nominal wage rigidity in village labor markets. American Economic Review, 109(10), 3585-3616.

Kwok, T. F., Xu, Y., Liu, X., and Leung, Y. (2018). The impacts of economic structure on china's carbon dioxide emissions: an analysis with reference to other east asian economies. Climate Policy, 18(10), 1235-1245.

Liddle, B. (2018). Warming and income growth in the united states: A heterogeneous, common factor dynamic panel analysis. Climate Change Economics, 9(04), 1850012.

Massetti, E., Guiducci, R. d. C. N., de Oliveira, A. F., and Mendelsohn, R. 
(2013). The Impact of Climate Change on the Brazilian Agriculture: A Ricardian Study at Microregion Level. CMCC, RP0200, 31.

Mendelsohn, R., Nordhaus, W. D., and Shaw, D. (1994). The Impact of Global Warming on Agriculture: A Ricardian Analysis. The American Economic Review, 84(4), $753-771$.

Oliveira, J. and Pereda, P. (2020). The impact of climate change on internal migration in brazil. Journal of Environmental Economics and Management, 103, 102340.

Pereda, P. C. and Alves, D. (2018). Climate and weather impacts on agriculture: The case of brazil. Economia Aplicada, 22(3), 5-26.

Pilcher, J. J., Nadler, E., and Busch, C. (2002). Effects of hot and cold temperature exposure on performance: a meta-analytic review. Ergonomics, 45(10), 682-698.

Ramsey, J. (1995). Task performance in heat: A review. Ergonomics, 38, 154-165.

Ranson, M. (2014). Crime, weather, and climate change. Journal of environmental economics and management, 67(3), 274-302.

Schlenker, W., Hanemann, W. M., and Fisher, A. C. (2005). Will U.S. Agriculture Really Benefit from Global Warming? Accounting for Irrigation in the Hedonic Approach. The American Economic Review, 95(1), 395-406.

Schlenker, W., Hanemann, W. M., and Fisher, A. C. (2006). The impact of global warming on us agriculture: an econometric analysis of optimal growing conditions. Review of Economics and statistics, 88(1), 113-125. 
Schlenker, W. and Lobell, D. B. (2010). Robust negative impacts of climate change on African agriculture. Environmental Research Letters, 5, 8.

Schlenker, W. and Roberts, M. J. (2009). Nonlinear temperature effects indicate severe damages to U.S. crop yields under climate change. Proceedings of the National Academy of Sciences, 106(37), 15594-15598.

Seppänen, O., Fisk, W., and Lei, Q. (2006). Effect of Temperature on Task Performance in Office Environment. Proceedings of the International Conference on Cold Climate Heating, Ventilating and Air Conditioning, 5th edition, 1-11.

Silva, W. K. d. M., Freitas, G. P., Junior, L. M. C., Pinto, P. A. L. d. A., and Abrahão, R. (2019). Effects of climate change on sugarcane production in the state of Paraíba (Brazil): a panel data approach (1990-2015). Climatic Change, 154(1-2), 195-209.

Somanathan, E., Somanathan, R., Sudarshan, A., and Tewari, M. (2018). The Impact of Temperature on Productivity and Labor Supply: Evidence from Indian Manufacturing. Working Paper, p. 70.

Sun, L., Li, H., and Ward, M. N. (2007). Climate Variability and Corn Yields in Semiarid Ceará, Brazil. Journal of Applied Meteorology and Climatology, 46, 226-240.

Welch, J. R., Vincent, J. R., Auffhammer, M., Moya, P. F., and Dobermann, A. (2010). Rice yields in tropical/subtropical Asia exhibit large but opposing sensitivities to minimum and maximum temperatures. Proceedings of the National Academy of Sciences, 107(33), 1452-14567. 
Wilde, J., Apouey, B. H., and Jung, T. (2017). The effect of ambient temperature shocks during conception and early pregnancy on later life outcomes. European Economic Review, 97, 87-107.

Xavier, A. C., King, C. W., and Scanlon, B. R. (2016). Daily gridded meteorological variables in Brazil (1980-2013). International Journal of Climatology, 36(6), 2644-2659.

Xavier, A. C., King, C. W., and Scanlon, B. R. (2017). An update of Xavier, King and Scanlon (2016) daily precipitation gridded data set for the Brazil. Proceedings of the Simpósio Brasileiro de Sensoriamento Remoto (SBSR), XVIII, 562-569.

Zhang, P., Deschenes, O., Meng, K., and Zhang, J. (2018). Temperature effects on productivity and factor reallocation: Evidence from a half million chinese manufacturing plants. Journal of Environmental Economics and Management, 88, 1-17.

Zivin, J. and Neidell, M. (2014). Temperature and the allocation of time: Implications for climate change. Journal of Labor Economics, 32(1), 1-26. 